\title{
A Bérgarancia Alap jelentösége a munkaügyi jogvédelem keretei között
}

\author{
The Importance of the Wage Guarantee Fund in the Framework \\ of Labour Law Protection
}

\begin{abstract}
ABSZTRAKT
A Bérgarancia Alapról szóló 1994. évi LXVI. törvény, illetve az általa szabályozott garanciarendszer vizsgálata napjainkban különösen aktuális, hisz a lassan két éve tomboló koronavírusjárvány okozta válság nyomaival összefüggésben egyre több munkáltató vált és válik fizetésképtelenné Magyarországon. Az eljárás alá vont munkáltatók pedig sok esetben nem képesek munkavállalóik irányába bérfizetési kötelezettségüket teljesíteni, így az államnak kell a pénzben egzakt módon kifejezhetó értékek - az elvégzett munka, illetve annak pénzbeli/anyagi ellentételezése -, és ezzel együtt a munkavállalók szociális biztonságának védelmét szavatolnia. Jelen tanulmányban a fizetésképtelen munkáltatók által teljesítendő munkabérek fedezetéül szolgáló Bérgarancia Alap alkalmazhatóságát vizsgáljuk az említett szociális biztonság, valamint a munkavállalók igényérvényesítésének szemszögéből.
\end{abstract}

Kulcsszavak: Bérgarancia Alap, munkaügyi jogvédelem, fizetésképtelenség, felszámolási eljárás

\begin{abstract}
Act LXVI of 1994 on the Wage Guarantee Fund and the guarantee system regulated by it, is especially topical nowadays, as more and more employers in Hungary have become insolvent in connection with the crisis caused by the coronavirus epidemic. In many cases, the employers subject to the procedure are not able to meet their wage obligations to their employees, so the state must guarantee the values that can be expressed in exact monetary terms - the work performed and its financial compensation - and at the same time the social security of employees. In the present study, we examine the applicability of the Wage Guarantee Fund, which serves to cover the wages to be paid by insolvent employers, from the perspective of the social security and the enforcement of employees' claims.
\end{abstract}

Keywords: Wage Guarantee Fund, labour law protection, insolvency, winding-up proceeding

A szabadversenyen alapuló piacgazdaság megjelenésével párhuzamosan megszaporodtak azon egyéni és társasvállalkozások, amelyek az egymással történő rivalizálás során a túlélésért kénytelenek küzdeni. E versengés eredmékényeképpen gyakori jelenség a gazdálkodó szervezetek fizetésképtelensége, amelynek legna-

* Dr. Sipka Péter, egyetemi adjunktus, Debreceni Egyetem Állam- és Jogtudományi Kar, Környezetjogi és Munkajogi Tanszék; ügyvéd, Dr. Sipka Ügyvédi Iroda, e-mail: peter.sipka@law.unideb.hu; Dr. Varga Dóra, PhD-hallgató, Debreceni Egyetem Marton Géza Állam- és Jogtudományi Doktori Iskola, e-mail: vargadora96@gmail. com. A tanulmány az Igazságügyi Minisztérium jogászképzés színvonalának emelését célzó programjai keretében valósult meg. 
gyobb áldozatai a munkavállalók, hiszen a munkáltatóknak olykor a fizetésképtelenségi eljárások során fennálló bérkövetelések kielégítésére sem volt elegendő forrásuk. Bár a munkavállalók követeléseinek biztosítása (legalábbis egyes részeiben) már a 20. század elején is megjelent, a rendszerváltást követően a korábban kialakított állami garanciák a csődeljárásról és felszámolási eljárásról szóló 1991. évi XLIX. törvény (a továbbiakban: Cstv.) hatálybalépésével megszűntek, így szükségessé vált egy olyan, a piacgazdaságon alapuló intézményrendszer létrehozása, ami biztosítja a bérkövetelések kielégítését. Ennek eredményeként született meg a Bérgarancia Alapról szóló 1994. évi LXVI. törvény (a továbbiakban: Bgtv., bérgarancia törvény), amivel a jogalkotó célja elsősorban a fizetésképtelen adós tartozásaiért való (korlátozott) ${ }^{1}$ helytállás biztosítása volt. ${ }^{2} \mathrm{~A}$ szabályozást a hatálybalépése óta több kritika is érte ${ }^{3}$ a joganyag elfogadásával azonban egyrészt hazánk az inszolvencia irányelv implementálásának kötelezettségét teljesítette, ${ }^{4}$ másrészt pedig létrehozott egy többé-kevésbé müködő rendszert, amely egy bizonyos szintig garantálja a fizetésképtelen munkáltató tartozásainak rendezését.

Tekintettel arra, hogy a koronavírus által előidézett veszélyhelyzet miatt a vállalkozások jelenleg is nehéz helyzetben vannak, a felszámolás alatt álló cégek száma ismét megemelkedett. ${ }^{5}$ Ezzel összefüggésben tehát újra elengedhetetlenné válhat a munkavállalói érdekek védelme, ami szükségképpen felveti annak a kérdését, hogy a jelenlegi jogi környezet alkalmas-e a megnövekedett munkavállalói igények kielégítésére. ${ }^{6} \mathrm{~A}$ dolgozatban ebből adódóan azt vizsgáljuk, hogy a jogszabály elfogadását követően huszonöt évvel milyen mértékben lehetséges a munkavállalói igények kielégítése ebböl az elkülönített pénzösszegböl, vagy megfordítva a kérdést: megfelelő igényérvényesitési eszköznek tekinthetö-e az érintettek szemszögéböl az állam által felállitott „védelmi intézmény”, vagyis a Bérgarancia Alap.

Hipotézisünk szerint a jogintézmény a jelenlegi forrás- és eljárási struktúrával nem alkalmas a kitüzött cél, nevezetesen a munkavállalói jogvédelem teljes körü eléréséhez, mivel sem eljárásrendjében, sem összegszerűségében nem igazodik a jelen kor követelményeihez.

${ }^{1}$ CsőKE Andrea: A Csődtörvény módosításának várható hatásai X. Céghírnök, 2006/12., 11.

${ }^{2}$ HoRESNY Julianna: Bérgarancia: A magyar szabályozás és annak gyakorlata. Pólay Elemér Alapítvány, Szeged, 2011, 9.

3 Prugberger Tamás-Törő Emese: Szociális és jogdogmatikai problémák a munkaviszony megszűnése és megszüntetése körül. Magyar Jog, 2018/1, 41.

${ }^{4}$ KISs György: Új foglalkoztatási módszerek a munkajog határán - az atipikus foglalkoztatástól a szerződési típusválasztási kényszer versus típusválasztási szabadság problematikájáig. Magyar Jog, 2007/1, 14.

${ }^{5}$ A veszélyhelyzet során több kisegítő lehetőség is adódott a nehéz körülmények közé került vállalkozások számára, lásd például a 179/2021. (IV. 16.) Korm. rendeletet, vagyis a „Reorganizációs Rendeletet”. A Reorganizációs Rendelet deklarált célja a veszélyhelyzet során a pénzügyi nehézségekkel küzdő vállalkozások vagyoni, pénzügyi, fizetőképességi helyzetének javítása és ezzel továbbműködésük biztosítása. Célját tekintve a reorganizációs eljárás a meglévő fizetésképtelenségi eljárások közül a csődeljárással mutat hasonlóságot, tekintettel arra, hogy mindkét intézmény fö célja a fizetési nehézséggel küszködö (fizetésképtelen vagy azzal fenyegetett) adós vállalkozás reorganizációja, azaz fizetőképességének helyreállitása. A kormányrendelet 2021. május 23. napjáig hatályos, azonban a veszélyhelyzet többszöri meghosszabbítása miatt elképzelhető, hogy a Reorganizációs Rendelet hatálya is meghosszabbításra kerül.

${ }^{6}$ JuHÁsz László: A csődtörvény 2020. évi módosításairól - veszélyhelyzeti szabályozás és aktuális változások a fizetésképtelenségi jogban. Gazdaság és Jog, 2021/2, 14. 
A kérdés megválaszolásához megvizsgáljuk az elmúlt három évnek az Alapból történő kifizetéseit, valamint az érintett időszak felszámolási eljárásaiban a felszámolók által benyújtott és később támogatott kérelmeket, amiből következtetéseket vonunk le a jogvédelem szintjét és minőségét illetően. Az adatokat az Innovációs és Technológiai Minisztérium szolgáltatta adatközlésre irányuló megkeresésünk alapján, így elsődleges forrásként ezt használtuk. Természetszerüleg megjelenik a tanulmányban a szekunder források elemzése és a vonatkozó szakirodalom lényegretörő áttekintése is.

Az elemzésünk módszertanát tekintve részben jogszabályelemzésen alapuló leíró, részben pedig statisztikai adatokon nyugvó empirikus módszert követ, elsősorban a hipotézis megválaszolásához szükséges mértékben és módon.

\section{A bérgarancia lényegi vonásai}

\subsection{A bérgarancia mint jogintézmény rendszertani elhelyezése}

A bérgarancia támogatás a bérgarancia törvény alapján megállapítható, visszatérítendő, kamatmentes támogatás, amelyet felszámolási vagy kényszertörlési eljárás alatt álló munkáltató vehet igénybe az általa foglalkoztatott munkavállalókkal szembeni bértartozásának rendezésére. A támogatás bevételeit a foglalkoztatás elősegítéséről és a munkanélküliek ellátásáról szóló 1991. évi IV. törvény (a továbbiakban: Flt.) 39. §-a (3) bekezdésének d) pontja alapján a foglalkoztatási programokkal kapcsolatos elkülönített állami pénzalap ${ }^{7}$ (a továbbiakban: Alap) bérgarancia alaprésze biztosítja. ${ }^{8}$

A bérgarancia helyét, funkcióját tekintve erős kettősség jelenik meg: egyrészt egy olyan, az állam által biztosított kezességvállalásról beszélhetünk, amely a fizetésképtelenségbe sodródott munkáltatónál foglalkoztatott munkavállalók munkabérének (legalább részbeni) kielégítését szolgálja, másrészt a fizetésképtelen munkáltatókkal szembeni védelmet szolgáló eszköz. A magyar jogirodalomban főként az elsődleges bérvédelmi funkció látszik elfogadottnak, ahogyan azt a KárolyiPrugberger szerzőpáros is hangsúlyozza írásában, amikor kijelenti, hogy a munkáltató fizetésképtelensége esetén a bérgarancia alaprészből történő kifizetés - alapvetően - a bérvédelemmel összefüggő munkajogi kérdés. ${ }^{9}$ Ezzel összefüggésben osztjuk Horesnyi álláspontját, amely szerint a bérgarancia törvényt nem tekinti a magyar fizetésképtelenségi jogot rendező alapvető szabálynak. Horesnyi véleménye szerint: „a munkajog szabályozási területéhez tartozó egyik alapvető normáról van

\footnotetext{
${ }^{7}$ Flt. 39. § (3) bekezdés d) pontja: Az Alapon belül - a pénzeszközök felhasználásának célja szerint - a következő alaprészeket kell elkülöníteni: a bérgarancia alaprészt, a Bérgarancia Alapról szóló 1994. évi LXVI. törvényben meghatározott támogatás, valamint az annak folyósításával kapcsolatos postaköltség finanszírozására.

${ }^{8}$ Bgtv. 1. $§(4)$ bekezdés.

${ }^{9}$ KÁROLYI Géza-PRUgBeRger Tamás: A magyar fizetésképtelenségi jog hatályos szabályozásának kritikai értékelése a nyugat-európai rendszerek tükrében. In: Bérgarancia és a csőd-, felszámolási eljárások reformja. Miskolc, Novotni Alapítvány a Magánjog Fejlesztéséért, 2005, 129.
} 
szó, amelynek léte és müködése megkérdőjelezhetetlenül összekapcsolódik a fizetésképtelenség szabályozásával, de semmiképpen sem része annak (hisz egy speciális pozícióban és jogviszonyban lévő »hitelező", speciális követeléséröl van szó, mely speciálisan, eltérő szabályok mentén - a bérgarancia alaprészen keresztül az állam által - kerül kielégítésre)."10 Mindezt alátámasztja a Prugberger-Törő szerzőpáros is, akik alapvetően a bérgarancia alap szociális aspektusait hangsúlyozzák. ${ }^{11}$

A fent említett kettősség megjelenik a nemzetközi jog keretei között is, ugyanis az ILO 173. számú Egyezményében taglalja a munkavállalók igényeinek védelmét a munkáltatójuk fizetésképtelensége esetén..$^{12} \mathrm{~A}$ dokumentum 5 . cikke kifejezetten védett igényként jelöli meg azt, hogy a munkavállalók igényét más hitelezők előtt elégítsék ki a fizetésképtelenség esetén, ami azt a szemléletet jeleníti meg, miszerint a bér(fizetés) mint erős szociális elemeket magában hordozó kötelmi jogi alapokon nyugvó kötelezettség megelőzi a kereskedelmi vagy más üzleti alapon nyugvó hitelezői igényeket. A hazai jogban a munkavállalói igényeket a Bgtv. kifejezetten rögzíti, amikor kimondja, hogy bértartozásnak minősül a felszámolás vagy kényszertörlési eljárás alatt álló gazdálkodó szervezetet - mint munkáltatót - terhelö, a Cstv. szerint felszámolási költségnek minősülö minden munkabértartozás, ideértve a betegszabadság időtartamára járó térítést, illetve a munkaviszony megszűnésével összefüggésben járó, a Cstv. 57 . § (3) bekezdése szerint elszámolható végkielégítés tartozást is. ${ }^{13}$

Összességében a bérgarancia definícióját tekintve egy olyan, az állam által gazdasági és szociális célból, illetve az EU-s tagságból adódóan kötelezően működtetett, bérvédelmet szolgáló, jogilag szabályozott intézmény, mely a munkavállalók fizetésképtelen munkáltatóikkal szemben fennálló bérköveteléseinek egy maximalizált mértékig való kielégítését biztosítja, állami forrásból. ${ }^{14}$

\subsection{A felszámolási eljárás és a bérgarancia összefüggései}

Ahhoz, hogy teljes képet vázolhassunk fel a munkáltatót érintő felszámolási eljárás és a bérgarancia között fennálló összefüggésröl, a jogszabályi alapoktól szükséges megközelítenünk azt.

Amennyiben a fizetésképtelenné vált gazdasági társaság ellen az illetékes bíróság felszámolási eljárást rendel el, és ezzel egyidejüleg megállapítja a fizetésképtelenségét, elindul az a nemperes (felszámolási) eljárás, amelynek a végén a társaság jogutód nélkül megszűnik. A felszámolás megindításával egy időben felszámolóbiztost jelölnek ki, aki a továbbiakban egyedül és önálóan lesz jogosult a társaság képviseletére, egyúttal a munkáltatói jogokat is gyakorolja. Ezzel összefüggésben felhívjuk

10 HORESNYI: i. m., 13.

11 Prugberger-Törö: i. m., 49.

12 Lásd bővebben az ILO 173. számú állásfoglalását: Protection of Workers' Claims (Employer's Insolvency) Convention, 1992. https://www.ilo.org/dyn/normlex/en/f?p=NORMLEXPUB:12100:0::NO::P12100_ILO_ CODE:C173 (2021. 05. 26.).

$180{ }^{13}$ Bgtv. 1. $\S(2)$ bekezdés $\left.d\right)$ pont.

${ }^{14}$ Horesnyl: i. m., 14. 
a figyelmet, hogy a bírói gyakorlat alapján a felszámoló kártérítési felelősséggel tartozik a felszámolási költségek - a Bérgarancia Alapból nyújtott támogatás - esedékességkor történő kielégítésének elmulasztása miatt, ha annak akárcsak részbeni megfizetésére az adós - a felszámolás alatt - pénzeszközzel rendelkezett, azonban azt a felszámoló nem az esedékes felszámolási költség kifizetésére fordította. ${ }^{15}$

A felszámolási eljárás kezdetekor a felszámoló a korábbi vezető tisztségviselő segítségével feltérképezi a cég vagyoni helyzetét, hitelezői igényeit, melybe szükségképpen beletartozik a munkavállalók igényeinek számbavétele. A felszámolás alatt álló céggel szembeni követelések kiegyenlítésének sorrendjét törvény határozza meg, azok közül a csődeljárásról és a felszámolási eljárásról szóló 1991. évi XLIX. törvény (a továbbiakban: Cstv.) 57. § (1) bekezdés szerint első helyen szerepelnek a felszámolás (2) bekezdés szerinti költségei. Ezen felszámolási költségek között szintén első helyen található az adóst terhelő munkabér és egyéb bérjellegü juttatások; ideértve a munkaviszony megszűnésekor járó végkielégítést, a kollektív szerződésben, illetve a munkaszerződésben meghatározott juttatásokat, valamint a munkáltatót a munkaviszony jogellenes megszüntetésével összefüggésben terhelő fizetési kötelezettségeket is; valamint az adós által a kölcsönbeadóval kötött munkaerő-kölcsönzési szerződésben foglalt, az adóst mint kölcsönvevőt terhelő díjból az adóshoz kölcsönzött munkavállalók részére járó, a kölcsönbeadó által fizetendő munkabért és egyéb bérjellegü juttatásokat. Ha a felszámolás kezdő időpontját megelőzően esedékessé vált munkabért és egyéb bérjellegü juttatásokat a felszámoló a felszámolás kezdő időpontja után fizette ki, az ezeket terhelő adó- és járulékfizetési kötelezettség is e körbe sorolandó.

Fontos megjegyeznünk, hogy a jogszabály nem minden munkavállalói követelésnek ad helyt a felszámolási eljárás során. A munkavállalói követelés ugyanis mást jelent a munkajog területén, és mást jelent a bérgarancia-szabályozás területén. Ha munkavállalói oldalról nézzük a kérdést, akkor az lenne az optimális megoldás, ha minden, a munkaviszonyból származó követelés a bérgarancia kifizetés tárgya lenne. Ez a megoldás azonban meglehetősen megterhelné az állami költségvetést, és talán nagyobb visszaélésekhez is vezetne. A törvény alapján csak az általa meghatározott, úgynevezett bértartozások sorolhatók a támogatási tárgykörbe. Bértartozásnak minősül a felszámolás alatt álló gazdálkodó szervezetet mint munkáltatót terhelő minden munkabértartozás, ideértve a betegszabadság időtartamára járó térítést is, és utalószabályként a munkaviszony megszünésével összefüggésben járó, a Cstv. 57. §-ának (3) bekezdése szerint elszámolható végkielégítés tartozást. ${ }^{16}$ Felhívjuk a figyelmet arra, hogy - ahogyan az az idézett jogszabályhely alapján is észrevehető - a bérgarancia törvény nem taglalja a munkabértartozás elemeit, így

\footnotetext{
${ }^{15} \mathrm{EBH} 2011.2331$.

${ }^{16}$ Cstv. 57. § (3): „A munkáltató rendes felmondása esetén felszámolási költségként - ha a felszámolás kezdő időpontját megelőzően legalább egy évvel korábban megkötött kollektív szerződés, illetve munkaszerződés magasabb összeget nem állapít meg - a munkavégzés alóli felmentés időtartamára jutó távolléti díj és a végkielégítés azon összege vehető figyelembe, amely a munkavállalót az Mt. 69. § (1)-(3) bekezdése, 70. § (3) bekezdése és 77. § (3) és (4) bekezdése alapján megilleti. E rendelkezés alkalmazásában az adós -

(1) bekezdés hc) pontjában nem említett - vezető állású munkavállalói tekintetében kizárólag az Mt. 210. §

(3) bekezdésében megállapított, a felszámolás kezdő időpontjában esedékes összeg vehető figyelembe."
} 
- mintegy háttérjogszabályként - a Munka törvénykönyvéröl szóló 2012. évi I. törvény (a továbbiakban: Mt.) vonatkozó rendelkezéseit ${ }^{17}$ kell figyelembe venni, amely törvény ugyan szintén nem tartalmazza a munkabér ${ }^{18}$ egzakt fogalmát, de a következő bérelemeket említi: a) alapbér, b) bérpótlék, c) rendkívüli munkavégzés ellenértékeként járó pótlék, illetve átalány, $d$ ) készenlét, ügyelet esetén járó juttatás, e) munkaszüneti napon a munkaidő-beosztás alapján munkát végző munkavállaló juttatása, $f$ ) állásidőre járó juttatás, $g$ ) távolléti díj. A fenti jogcímen járó juttatások bérgarancia alapból való kifizethetősége tehát megkérdőjelezhetetlen a hivatkozott jogszabályi rendelkezések alapján.

Összegezve tehát, a Bérgarancia Alapból jelenleg megtéríthető követelések két csoportba sorolhatóak: egyrészt beszélhetünk munkabértartozásról (beleértve a betegszabadság idejére járó juttatást is), másrészt végkielégítés tartozásról. ${ }^{19}$ Ezek a követelések a bérgarancia törvény értelmében csak akkor képezhetik a támogatás alapját, ha fennálló bértartozásról van szó, hiszen ahogyan Kiss György rámutat: „a munkavállaló teljesitését követöen - törvényben meghatározott időponttól kezdve a követelés esedékes, és a munkáltató, mint adós késedelemben van". ${ }^{20}$

A fentiekben láthattuk, hogy a Bgtv. felszámolásra vonatkozó alapszabálya kitér az „általános” gazdálkodó szervezetnek a munkavállalóval szemben fennálló kiegyenlítetlen bértartozásain túl a munkaerö-kölcsönzés keretében történő foglalkoztatás során, illetve az iskolaszövetkezet, valamint a közérdekű nyugdíjas szövetkezet részére meg nem fizetett díjakra is. ${ }^{21}$

Utóbbiak a közelmúlt jelentős módosításainak eredményei. A 2012. évi CXCVII. törvény a munkaerő-kölcsönzés keretében történő munkavégzésről szóló 2008/104/EK irányelv alapján a kölcsönvevő cég felszámolása esetén a kölcsönzött munkavállalók szociális biztonsága, a munkabérhez való joguk védelme érdekében módosította az érintett szabályokat. ${ }^{22} \mathrm{E}$ módosítás értelmében a felszámolási költségek között elöresorolásra került és az adóst terhelő munkabér, valamint egyéb bérjellegủ juttatások közé tartozik egyrészt a munkaerö-kölcsönzésről szóló szerződésben foglalt, az adóst az Mt. szerint kölcsönvevőként terhelő, a kölcsönbeadónak járó kölcsönzési díjból a kölcsönzött munkavállalók részére járó munkabér, egyéb bérjellegű juttatások és az ezeket terhelő adó és járulék együttes összege. Ez kiegészül

\footnotetext{
${ }^{17}$ A munka díjazásáról az Mt. XII. fejezetében találunk rendelkezéseket.

${ }^{18}$ A munkabérrel kapcsolatban bővebben lásd: RAB Henriett-ZACCARIA Márton Leó: Az egyenlő munkáért egyenlő bér elv szerepe a munkajog aktuális tendenciái között, különös tekintettel az emberi erőforrás gazdálkodás egyes szempontjaira. JURA, 2016, 290-297; PRUGBERGER Tamás-NÁDAs György: Európai és magyar összehasonlító munka- és közszolgálati jog. Wolters Kluwer, Budapest, 2014, 253-281.

${ }^{19}$ EmBer Alex: A munkavállalók törvényes érdekeinek védelme a munkáltató fizetésképtelensége esetén, a Bérgarancia Alap. Jog, Állam, Politika, 2016/1, 31.

${ }^{20}$ KISs György: A szociális érzékenység kényszere és korlátai: a munkavállalói jogok védelme a munkáltató fizetésképtelensége esetén. Magyar Jog, 1999/2, 80.

21 1994. évi LXVI. törvény 1. § (1) bekezdés.

22 Bővebben lásd: NEMESKÉRI Zsolt-ÁsvÁNYI Zsófia-BANKó Zoltán-BARAKONYı Eszter-EgERSZEGI ZoltánKÁRTYÁs Gábor-LÁsZLó Gyula: A munkaerő-kölcsönzés alakulása, hatása a foglalkoztatásra és a gazdasági folyamatokra. In: Tamás Ildikó-Borbély-Pecze Tibor-Borsos József-Zagyiné Honti Éva-Munkácsy Ferenc (szerk.): Kutatási évkönyv: Összefoglalók a TÁMOP 1.3.1. kiemelt projekt keretében 2009 és 2011 között befejezett egyes kutatásokról. Budapest, Foglalkoztatási Hivatal, 2012, 257-275.
} 
az iskolaszövetkezettel és közérdekű nyugdíjas szövetkezettel kötött szerződésből eredő díjakkal is. A jogalkotó tehát a korábbi szabályozásokon túl a jogszabály tárgyi hatályát a bértartozásokon túl kiterjesztette a kölcsönzési díjra, valamint a szolgáltatási díjra is. A munkavállalók így szélesebb körben jogosultak bérvédelem iránti igényük előterjesztésére.

Mindazonáltal a bértartozás fennállása, mértéke a gyakorlatban nem állapítható meg ilyen egyszerüen, ugyanis olykor vékony a határvonal a vitatott összeg tekintetében: valóban bértartozás-e, vagy inkább kártérítési igényként érvényesítheti azt a munkavállaló?

A Kúria egy precedensképes határozatának ${ }^{23}$ alapjául szolgáló tényállás szerint az elsőfokú bíróság felperes munkavállaló határozatlan idejü munkaviszonyát jogellenesen megszüntető munkáltatóval szemben marasztaló ítéletet hozott, így annak meg kellett térítenie kártérítés jogcímén a munkavállaló elmaradt jövedelmét, valamint e tőkeösszeg kamatait is. Időközben azonban a munkáltató felszámolás alá került. A felszámoló a perbeli követelés támogatásként történő kifizetésére kérelmet terjesztett elő az illetékes közigazgatási szervnél. Ezt mind az elsőfokon eljáró hatóság, mind a fellebbezés folytán eljáró alperes elutasította. Indokolásában arra hivatkozott, hogy a követelés eredete elsődlegesen a munkáltató jogellenes magatartására vezethető vissza, és emiatt a felperest ért kár kompenzálásáról van szó, ami nem minősül munkabérvédelemnek. Jól látható, hogy a Kúriának egy összetett kérdésre kellett választ adnia: jelen ügyben a felperes igénye bértartozásnak vagy kártérítésnek minősül-e, és ha előbbinek, akkor kielégíthető-e bérgarancia-eljárás keretében?

Áttekintve a vonatkozó jogszabályok rendelkezéseit, a Kúria kimondta, hogy a jelen ügyben a megtérítési igény kifejezetten olyan elmaradt jövedelem iránti jogszerü követelés, amit a munkavállaló egyértelműen az adott helyzetben elvárhatóan nem tudott megkeresni, hiszen amit megkereshetett volna, azt a kártérítés - az Mt. 172. § (1) bekezdés $b$ ) pontja értelmében - nem foglalhatja magában. A jogosultságot megállapító ítélet lényegében ilyen elmaradt jövedelmet állapított meg, hiszen a munkaviszony jogellenes megszüntetésétől a bírósági ítélet meghozataláig terjedő időre mondta ki a munkabér összegére való jogosultságot. Ezzel összefüggésben - a már hivatkozott Cstv. 57. § (2) és (3) bekezdésének alapulvételével - megállapítható, hogy az elmaradt jövedelem elmaradt és várományos keresménynek tekintett része csakis felszámolási költségnek minősülő, az adóst terhelő munkabér lehet, amelynek kielégítése a Bgtv. 1 . $\S(2)$ bekezdésének $d$ ) pontja ${ }^{24}$ értelmében a Bérgarancia Alapból jogszerüen igényelhető.

A fentiekből jól látható, hogy a bérgarancia hazai normatív kerete a Bgtv., amely a hozzá kapcsolódó fontosabb szabályokkal kiegészülve elégíti ki a munkabér védelmével kapcsolatos elvárásokat, így nem elegendő e törvények alapvető szabá-

\footnotetext{
${ }^{23}$ A Kúria Kfv.35062/2018/5. számú precedensképes határozata.

${ }^{24}$ Bgtv. 1. § (2) bekezdés d) pont: „bértartozás: a felszámolás vagy kényszertörlési eljárás alatt álló gazdálkodó szervezetet - mint munkáltatót - terhelö, a Cstv. szerint felszámolási költségnek minősülő minden munkabértartozás, ideértve a betegszabadság időtartamára járó térítést is, és a munkaviszony megszünésével összefüggésben járó, a Cstv. 57. § (3) bekezdése szerint elszámolható végkielégítés tartozás."
} 
lyainak áttekintése, szükség van a fennálló szoros kapcsolat hangsúlyozására is. Ennek a gyakorlatban is nagy szerepe van, tekintettel arra, hogy a bíróságok egyre gyakrabban kerülnek nehéz helyzetbe egy-egy elmaradt munkabérrel összefüggő munkavállalói igényérvényesítés kapcsán.

\section{A Bérgarancia Alap mint igényérvényesítési eszköz alkalmazhatósága}

Az eddigi áttekintés alapján levonható az az alapvető konklúzió, hogy a bérgarancia törvény alaptézise nem más, mint a felszámolás alatt áló gazdálkodó szervezetek munkavállalóival szembeni kiegyenlíthetetlen bértartozásának megelölegezése. Ezzel összefüggésben az intézmény tehát a munkavállalók igényérvényesítésének, a munkabér védelmének egyik potenciális eszköze lehet abban az esetben, ha megfelelő jogszabályi - és nem utolsósorban - finanszírozási keretekkel van felruházva. Ebből következően értelemszerüen felmerülhet a kérdés, hogy vajon a jogalkotó célkitűzése a gyakorlatban mennyiben valósul meg, azaz ténylegesen milyen mértékben ad pénzügyi biztonságot az alap. Ehhez elsősorban a munkavállalók szemszögéből szükséges megvizsgálnunk a Bérgarancia Alapot mint igényérvényesítési eszközt. 25

A Bgtv. mint a munkavállalók érdekeit védő norma, illetve az ezen alapuló garanciarendszerrel szembeni, rendszeresen visszatérö - és a hipotézisünkben is megjelenő - kritika, hogy az föként az egyenlő bánásmód követelményét sértve, nem biztosít védelmet a munkavállalók teljes köre számára. ${ }^{26} \mathrm{E}$ kritika a Bgtv. alaptéziséből ered, amely szerint a bérgarancia-eljárás keretében a felszámolás alatt álló gazdálkodó szervezetnek a munkavállalóval szemben fennáló, kiegyenlítetlen bértartozása előlegezhető meg. ${ }^{27} \mathrm{~A}$ normaszöveg szerint tehát nem a munkavállaló jelenti a kulcspozíciót, tekintettel arra, hogy e rendelkezés alapján csak azon munkáltatók-

${ }^{25}$ A munkavállalói jogérvényesitéssel kapcsolatban lásd bővebben NÁDAs György-RAB Henriett: Az Alkotmánybíróság munkajogi jogvédelmet alakító szerepe az aktuális gyakorlat alapján. In: Auer Ádám-Berke GyulaGyörgy István-Hazafi Zoltán (szerk.): Ünnepi kötet a 65 éves Kiss György tiszteletére [Liber Amicorum in honorem Georgii Kiss aetatis suae LXV]. Dialóg Campus, Budapest, 2018, 695-706.

${ }^{26}$ Kikerülnek a védelem alól például az egyéni vállalkozók és az általuk foglalkoztatottak, az állami és költségvetési szféra munkáltatói és az általuk közszolgálati, közalkalmazotti jogviszonyban, munkaviszonyban foglalkoztatottak, vagy a rendvédelmi szervek, a Magyar Honvédség szerződéses állományban dolgozó tagjai. Ezzel összefüggésben lásd Laky Teréz: Háttértanulmány az inszolvencia hazai szabályozásának néhány kérdéséhez. Budapest, 2000. http://static.hlt.bme.hu/laky/Cikk/inszolvencia.pdf (2021. 05. 31.).

${ }^{27}$ A Cstv. 3. § (1) alapján gazdálkodó szervezet: „aa) a magyarországi székhellyel rendelkező gazdasági társaság, közhasznú társaság, ügyvédi iroda, közjegyzői iroda, szabadalmi ügyvivői iroda, végrehajtói iroda, európai részvénytársaság, szövetkezet, lakásszövetkezet, európai szövetkezet, vízgazdálkodási társulat (a víziközmü-társulat kivételével), erdőbirtokossági társulat, önkéntes kölcsönös biztositó pénztár, magánnyugdijpénztár, egyéni cég, egyesülés - ideértve az európai gazdasági egyesülést is -, európai területi társulás, egyesület, alapítvány, valamint ab) mindazon egyéb jogi személy vagy jogi személyiséggel nem rendelkezö, a személyes joga alapján gazdasági társaság vagy más, gazdasági tevékenységet folytató szervezet, amelynek a fö érdekeltségeinek központja - a fizetésképtelenségi eljárásról szóló, 2015. május 20-i (EU) 2015/848 európai parlamenti és tanácsi rendelet (a továbbiakban: 2015/848 EU rendelet) alapján - az Európai Unió területén található, és az ellene inditható fizetésképtelenségi eljárás a 2015/848 EU rendelet hatálya alá esik." 
kal munkaviszonyban áló munkavállalók követeléseinek kielégítése lehetséges az alaprészből, amelyek az irányadó jogszabályi rendelkezések figyelembevételével felszámolási eljárás alá vonhatóak. ${ }^{28}$

Az említett alaptézis okán le kell szögeznünk, hogy az egyes bérkövetelések Bérgarancia Alapból való kielégítésére csak abban az esetben van lehetőség, ha az illetékes bíróság jogerősen elrendelte a felszámolást. ${ }^{29}$ Ehhez kapcsolódóan szükséges megemlítenünk a „látens fizetésképtelenség” fogalmát. A gyakorlatban ugyanis bebizonyosodott, hogy a Bgtv. által alapul vett Cstv.-beli fizetésképtelenség alapvetően a gazdasági partnerekkel, illetve a hitelező pénzintézetekkel szemben releváns, a munkavállalók felé ezzel a látens fizetésképtelenség képét vetítve, amelyet egy későbbi fizetés reményében a munkavállaló kénytelen eltürni. ${ }^{30}$

További komoly problémát jelent az akár több havi munkabértartozásával érintett munkavállalókkal kapcsolatban, hogy gyakran nincsenek tisztában „hitelezői” mivoltukkal, így az alaprész igénybevételére gyakran csak akkor kerül sor, ha valamely más hitelező megindítja a felszámolási eljárást, ezzel megoldva a munkavállalók helyzetét, tekintettel arra, hogy ebben az esetben a felszámolónak nemcsak lehetösége, hanem kötelezettsége az elmaradt munkabérek fedezetéül szolgáló támogatási eljárás megindítása. ${ }^{31}$

Ezzel összefüggésben szükségesnek tartjuk megjegyezni, hogy az elöbb említett „„út”, amellyel a munkavállalók hozzájuthatnak az őket megillető bérükhöz, hoszszadalmasnak tekinthető, így a törvény által biztosítani kívánt szükséges szociális biztonság veszélyeztetett. Erre megoldásként több szerző is felvázolta annak a lehetőségét, hogy bizonyos esetekben maguk a munkavállalók - tehát a felszámoló kihagyásával - közvetlenül igényelhessék elmaradt járandóságukat a bérgarancia alaprészből. ${ }^{32} \mathrm{E}$ körben csatlakozunk Horesnyi álláspontjához, aki felveti, hogy a fenti eset komoly anyagi és eljárásjogi ismereteket kívánna meg a munkavállalóktól. Ezek hiánya olyan igényérvényesítési hibák felmerülését (mint például a helytelenül kiszámított támogatási összeg, fontos igazolások mellékletként történő csatolásának elmaradása) generálná, amelyek nem az eljárás menetének, idejének rövidítésével járnának, hanem inkább költségesebbé, hosszadalmasabbá, bonyolultabbá tennék azokat az eljáró közigazgatási hatóságok leterhelése miatt. ${ }^{33}$

A szakirodalomban megjelenő - Wagner Ildikó már hivatkozott müvében - felvázolt elképzelés szerint „segítene az elmaradt bérükre hónapok óta váró munkaválla-

\footnotetext{
${ }^{28}$ KISs György: A munkavállalói jogok védelme a munkáltató fizetésképtelensége esetén. In: Bankó ZoltánBerke Gyula-Birk, Rolf-Gyulavári Tamás-Kiss György-Ladó Mária (szerk.): Az Európai Unió munkajoga és a magyar munkajog a jogközelítés folyamatában. Osiris, Budapest, 2001, 301.

${ }^{29}$ E hiányosságot hangsúlyozza Wagner is. WAGNER Ildikó: A munkáltatói és munkavállalói fizetésképtelenség összefüggései. Themis, 2007. december, 125.

${ }^{30}$ KISs (1999): i. m., 75.

${ }^{31}$ Tekintettel arra, hogy a munkabérek biztosítására vonatkozó rendelkezések csak a már megindult felszámolási eljárásban alkalmazandók, az ebből eredő kötelezettségek a felszámolót terhelik. Lásd bővebben: BANKó Zoltán-BERKE Gyula-KIss György: A munkáltató fizetésképtelensége. Az Európai Unió szociális dimenziója. OFA, Budapest, 2004, 141-143.

${ }^{32}$ Lásd például PRUGBeRger Tamás: A bérgarancia. In: Szekeres Mónika-Paár Ambrus Mariann (szerk.): Elbocsátás, felmondás, végkielégítés. Fórum Média, Budapest, 2006, 3.; EMBER: i. m., 41.

${ }^{33}$ HORESNYI: i. m., 156.
} 
lók helyzetén, ha az Alapból történő kifizetés egyböl részükre történne, a felszámoló közbeiktatása nélkül" ${ }^{34}$ Ezen alternatíva a jogalkotó részéröl is megfontolásra érdemessé vált, ennek eredményeképp pedig a 2013. évi CLXXIX. törvénnyel módosításra került Bgtv. szerint a bérgarancia-támogatás odaítélése esetén a támogatást nem a gazdálkodó szervezet pénzforgalmi számlájára kell utalni, hanem a bértartozásnak a törvényben meghatározott összegét az állami foglalkoztatási szerv közvetlenül a munkavállalóknak fizeti ki. ${ }^{35} \mathrm{E}$ módosításra legföképp azért volt szükség, mert a gyakorlatban gyakran előfordult, hogy a felszámolás alatt álló gazdálkodó szervezetnek nem volt pénzforgalmi számlája, mivel azt a felszámolók a felelős gazdálkodás és költséghatékonyság jegyében megszüntették, vagy nagyobb összegủ tartozás esetén maguk a bankok tették ugyanezt. ${ }^{36}$

A fentieken túlmenően, a felszámolási eljárás befejező időpontjával összefüggésben kiemelendő azon munkavállalói csoportok helyzete, amelyek munkaviszonyával kapcsolatban az Mt.-ben szereplő jogszabályi előírás tiltja vagy korlátozza a jogviszony munkáltató általi egyoldalú, „rendes” megszüntetését. Esetükben ugyanis nem lehetséges az alapvető szabályok szerinti munkáltatói felmondás. Az Mt. 65. § (3) bekezdése értelmében „[a] munkáltató felmondással nem szüntetheti meg a munkaviszonyt a) a várandósság, b) a szülési szabadság, c) a gyermek gondozása céljából igénybe vett fizetés nélküli szabadság, d) a tényleges önkéntes tartalékos katonai szolgálatteljesítés, valamint e) a nő jogszabály szerinti, az emberi reprodukciós eljárással összefüggő kezelésének, de legfeljebb ennek megkezdésétöl számított hat hónap tartama alatt".

Fontosnak tartjuk kiemelni, hogy a felmondási tilalmak - nevükböl fakadóan csak a felmondás esetén nyújtanak védelmet a munkavállalónak, közös megegyezés és azonnali hatályú felmondás esetén nem. ${ }^{37}$ Ezzel összefüggésben szükséges kitérnünk a várandósság, illetve az e) pontban szabályozott, a nők jogszabály szerinti, az emberi reprodukciós eljárással összefüggő kezelésének kérdéskörére, ${ }^{38} \mathrm{ez}$ ugyanis az Mt. 65. § (5) bekezdésében foglalt többletkövetelménnyel társul, ami pedig nem más, mint a várandós munkavállaló tájékoztatási kötelezettsége. Ezzel összefüggésben megemlítendő, hogy a korábban hatályos Munka Törvénykönyvéröl szóló 1992. évi XXII. törvény (a továbbiakban: régi Mt.) alapján akkor is jogel-

\footnotetext{
${ }^{34}$ WAGNER: i. m., 126.

${ }^{35} \mathrm{E}$ tekintetben érdekes gondolatot vet fel Ember Alex a támogatás ügyvédi letéti számlára való utalásáról. EMBER: i. m., 42.

36 JuHÁsz László: A magyar fizetésképtelenségi jog kézikönyve II. HVG-ORAC, Budapest, 2016, 1090.

${ }^{37}$ E rendelkezést szem előtt kell tartani a csoportos létszámcsökkentés esetén is. Bővebben lásd: JAKAB NóraPRUgBerger Tamás: A felmondásvédelem - a csoportos létszámleépítés uniós szabályai. In: Zaccaria Márton Leó-Jakab Nóra (szerk.): Az európai munkajog vázlata/Abriss des europäischen Arbeitsrechts: A munkajog uniós intézményeinek strukturális csomópontjai/Die Strukturknotenpunkte der arbeitsrechtlichen Institutionen der Europäischen Union. Debrecen, Lícium-Art, 2016, 99-108.

${ }^{38} \mathrm{Az}$ egyenlő bánásmód követelményének témakörében felmerülö problémákra lásd ZAccARIA Márton Leó: Az egyenlő bánásmód elvének érvényesülése a munkaviszony létrehozásával összefüggésben. Miskolci Jogi Szemle, 2014/2, 128-144.; SIPKA Péter-ZAcCARIA Márton Leó: A munka és magánélet közötti egyensúly kialakításának alapvető követelményeiről a 2019/1158 irányelvre figyelemmel. Munkajog, 2020/1, 24-30.; SIPKA Péter-ZACCARIA Márton Leó: Részmunkaidős, szülő, nő: a több védett tulajdonságot is érintő közvetett diszkrimináció lehetősége a felmondásnál. Munkajog, 2020/4, 33-39.
} 
lenes volt a felmondás, ha maga a munkavállaló sem tudott a felmondás idején a terhességéröl. ${ }^{39}$

Ehhez képest változást jelentett a 2012. évi törvény, amely alapján eredetileg a felmondás közlését megelőzően kellett tájékoztatni a munkáltatót a terhesség fennállásáról ahhoz, hogy a felmondási tilalommal élhessen a munkavállaló, ezt azonban az Alkotmánybíróság a 17/2014. (V. 30.) AB határozatával részben megsemmisítette azzal, hogy kimondta: „a szabályozási koncepció szempontjából a várandós munkavállalók tartoznak homogén csoportba. A várandósság első időszakában azonban a nők sok esetben maguk sem tudnak a várandósságukról. Az Mt. 65. § (5) bekezdése viszont attól függetlenül ír elö 'a felmondás közlését megelőző' tájékoztatási kötelezettséget, hogy a munkavállaló nő tudomást szerzett-e a felmondási védelemre okot adó állapotról. Azok, akik nem tudnak a várandósságukról, 'a felmondás közlését megelőzően' kitétel miatt utólag nem tudják érvényesíteni a felmondási védelmet. Az Alkotmánybíróság már a fentiekben megállapította, hogy a jogalkotónak széles körü mérlegelési lehetösége van abban, hogy a felmondási védelmet milyen körben és hogyan biztositja. Ha azonban feltételt szab a felmondási védelem érvényesitéséhez, ennek során az érintetteknek esetlegesen eltérő egyéni szempontjai megfelelő figyelembevételével kell eljárnia. A jogalkotó azon munkavállalók számára, akik még nem szereztek tudomást a várandósságukról, lehetetlen feltételt szab a felmondási védelem érvényesitéséhez. Ez a feltétel nem következik sem a felek közötti együttmüködés követelményéböl, sem a tájékoztatás rendeltetéséböl. Mivel a jogalkotó - az egyéni szempontok figyelmen kívül hagyásával - a felmondási védelem érvényesitése szempontjából tárgyilagos mérlegelés szerinti ésszerütlen okból tett különbséget a várandós nők között, az Mt. 65. § (5) bekezdése 'a felmondás közlését megelőzően' szövegrésze az Alaptörvény XV. cikk (1) bekezdésébe ütközik." ${ }^{40}$

A fentiek alapján jól látható, hogy a várandósság, illetve a reprodukciós eljárásban való részvétel megítélése rendkívül összetett és bonyolult helyzetet szül nemcsak a munkáltató felmondása, hanem annak fizetésképtelensége esetén is. Tekintettel arra, hogy az idézett törvényszövegben található taxatíve felsorolt esetekben tilos a munkáltató, illetve a felszámolási eljárásban annak pozíciójába lépő felszámoló általi rendes felmondás, megnehezül az érintett munkavállalók bérigényének az Alapból történő kielégítése.

A gyakorlatban e problémával az előbb említett munkavállalói csoporton túlmenöen főként a gyermek gondozása céljából fizetés nélküli szabadságon lévő nők és férfiak érintettek. Esetükben ugyanis a fentiek szerinti felmondási védelem akadályozza meg a felszámoló működési okkal összefüggő rendes felmondását, ami kizárja az ahhoz füződő járandóságokhoz a bérgarancia alaprészből - a munkáltató más munkavállalóihoz hasonlóan - való hozzájutást, erősen sértve ezzel az esélyegyenlőség elvét. ${ }^{41}$ Ebben az esetben a legfőbb probléma az, hogy a munkaviszony

\footnotetext{
${ }^{39}$ Bővebben lásd KAJTÁR Edit: Miért nem szólt? A várandósságra vonatkozó tájékoztatási kötelezettség munkajogi szemszögből. Infokommunikáció és Jog, 2014/2, 92-96.; PETRovics Zoltán: Miért kell védeni? A munkajogviszony munkáltató általi megszüntetésével szembeni védelem egyes kérdéseiről. Munkajog, 2017/1, $4-11$.

40 17/2014. (V. 30.) AB határozat 45. pont.

${ }^{41}$ Horesnyi: i. m., 160.
} 
megszűnésének módja a munkáltató jogutód nélküli megszűnése, amely a bíróság felszámolási eljárást megszüntető és a cégnyilvántartásból való törlést elrendelő jogerős végzésével megy végbe, vagyis a cég már nem áll felszámolási eljárás alatt, így az Alapból történő munkavállalói munkabérigények kielégítése lehetetlenné vált. Ez hátrányos helyzetet teremtett a fent említett munkavállalók számára, hiszen a munkáltató egyéb alkalmazottjai javarészt hozzájuthattak járandóságukhoz, ellentétben velük, akik elestek e lehetőségtöl.

A fent részletezett anomáliára jelentett megoldást a törvényhozó részéröl a Bgtv. módosítása. Ennek értelmében „azon munkavállalókkal szembeni bértartozást, akiknek a munkaviszonya az Mt. 63. § (1) bekezdés b) pontja alapján a munkáltató jogutód nélküli megszünése miatt szünik meg, továbbá azt a bértartozást, amely a gazdálkodó szervezet jogutód nélküli megszünésének időpontjában válik esedékessé, a felszámoló köteles rendelkezésre álló fedezet hiányában - a munkavállaló külön igénybejelentése nélkül - a felszámolási zárómérleg elkészítését megelőzően az Alap bérgarancia alaprészéből megigényelni. A bértartozás kifizetésére az 5. §-ban foglaltakat megfelelöen alkalmazni kell". ${ }^{42}$

Ezzel kiküszöbölték a bérgarancia-rendszerrel kapcsolatban felmerült és a fentiekben részletezett legégetőbb problémát: a „speciális helyzetü”, körülményeikből adódóan felmondási védelemmel bíró munkavállalói csoportok munkabére megfizetésre kerülhet az Alapból, külön igénybejelentés nélkül. Mindazonáltal az elmaradt munkabérek összegszerüségében felső határt szabott a jogalkotó azzal, hogy a törvény már idézett szakaszában rögzíti: „A felszámoló a támogatási igény meghatározása során a támogatásra jogosult gazdálkodó szervezetnek a jogosultakkal szemben, a bérfizetési napon fennálló bértartozását, de egy felszámolási eljáráson belül jogosultanként legfeljebb a tárgyévet megelőző második év - Központi Statisztikai Hivatal által közzétett - nemzetgazdasági havi bruttó átlagkeresetének (a továbbiakban: bruttó átlagkereset) ötszörösét veheti figyelembe. Ha a gazdálkodó szervezet a támogatást ugyanazon jogosult tekintetében egy felszámolási eljáráson belül több részletben veszi igénybe, és a felszámolási eljárás egyes naptári éveiben a bruttó átlagkereset mértéke eltérő, - a támogatás következő évben történő igénybevétele esetén - a jogosultság szempontjából a magasabb bruttó átlagkereset alapján számított támogatási mértéket kell figyelembe venni."

Jól látható, hogy a munkavállalói kör bővítésével, illetve az állami foglalkoztatási szerv közvetlenül az érintett foglalkoztatottak számára történő teljesítésével kapcsolatos módosításokkal a jogalkotó igyekszik bővíteni a munkavállalói igényérvényesítés körét, lehetőséget teremtve a Bérgarancia Alap minél szélesebb körü kihasználására.

\subsection{A Bérgarancia Alap által nyújtott támogatások számszaki adatai}

Az Innovációs és Technológiai Minisztérium adatközlése szerint az elmúlt három évben a Bérgarancia Alapból történő támogatás igénylése folyamatosan csökkenő 
tendenciát mutat: 2018-ban 1025 kérelem érkezett az illetékes kormányhivatalokhoz, amelyből 940 került támogatásra, ez 91,7\%-os finanszírozottságot jelent. Ezt némiképp alulmúlta a 2019. évben igényelt és támogatott kérelmek száma, ugyanis a 854 igénylésből 745 nyert támogatást, ezzel 87,2\%-ban hasznosították a Bérgarancia Alapot a bértartozások kielégítésére. A tavalyi évben szintén csökkenő tendenciát mutatott az igénylések száma: a mindösszesen 692 igénylésből 597 került támogatásra, ami 86,3\%-os támogatottságot jelent.

A fenti adatokkal kapcsolatban megjegyezzük, hogy azok területi eloszlása egyre szűkül, az igénylésekben érzékelhető csökkenő tendencia pedig a kezdődő központosításnak is köszönhetö, tekintettel a nemrégiben bekövetkezett módosításra. Eddig a Bgtv. 4. $\S(2)$ bekezdése szerint a támogatás iránti kérelem elbírálására vonatkozó eljárásra az az állami foglalkoztatási szerv volt illetékes, amelynek területén a felszámolás alatt álló gazdálkodó szervezet székhelye, ennek hiányában fióktelepe, telephelye volt. Ha a gazdálkodó szervezet nem rendelkezett magyarországi székhellyel, fiókteleppel vagy telephellyel, akkor a támogatási igény elbírálására vonatkozó eljárás lefolytatására az állami foglalkoztatási szervként eljáró Budapest Főváros Kormányhivatala vált illetékessé. A jogszabály módosításával ebben 2020. március 1-jétöl változás következett be: a támogatás iránti kérelem elbírálására vonatkozó eljárás lefolytatására a Kormány által kijelölt állami foglalkoztatási szerv az illetékes, amely Budapest Főváros Kormányhivatala.

Az Alapból történő forráslehívás sikeressége nagymértékben függ a felszámolók eljárásától is. Míg 2018-ban 45 kérelemmel kapcsolatban szüntették meg az eljárást a hiánypótlási felhívás sikertelensége vagy a kérelemnek felszámoló általi visszavonása miatt, addig ez a szám 2019-ben 62-re, 2020-ban pedig 70-re növekedett. Ezen adatok mellett szinte eltörpülni látszik a hatóság által elutasított kérelmek aránya, amely 2018-ban 39, 2019-ben 44, míg a 2020. évben 20 darab igénylést érintett. ${ }^{43}$

A feldolgozott információkból azt a következtetést vonhatjuk le, hogy a felszámolási eljárások során a Bérgarancia Alapból történő bértartozások kielégítésére irányuló kérelmek száma a vizsgált időszakban minimálisan csökkent, amivel az eredményességnek - vagyis a támogatások kiutalásának - fordítottan arányosnak kellene lennie. $E$ hatásosság elmaradásának hátterében részben a finanszírozási keret szükössége, részben pedig a kérelem felszámolók általi visszavonása vagy a hiánypótlás elmulasztása áll. Az igényérvényesítés bővítésével összefüggő jogalkotói álláspont a fent ismertetett és vizsgált időszakban kevésbé érvényesült, föként az eljárás eredménytelensége miatt. Az erre irányuló törekvéssel összefüggésben az alanyi kör további bővítésére, illetve az eljárás egyszerűsítésére irányuló módosításokra lenne szükség, hogy a Bérgarancia Alap teljesíthesse feladatát: a munkavállalói bérigények teljes körü kielégítését.

\footnotetext{
${ }^{43} \mathrm{Az}$ adatok szolgáltatásáért köszönetünket fejezzük ki az Innovációs és Technológiai Minisztériumnak.
} 
1. táblázat. A Bérgarancia Alappal kapcsolatos kérelmek alakulása, 2018-2020

\begin{tabular}{|l|c|c|c|}
\hline & $\mathbf{2 0 1 8}$ & $\mathbf{2 0 1 9}$ & $\mathbf{2 0 2 0}$ \\
\hline Összes kérelem & 1025 & 854 & 692 \\
\hline $\begin{array}{l}\text { Visszautasított } \\
\text { kérelem }\end{array}$ & 1 & 3 & 5 \\
\hline $\begin{array}{l}\text { Megszüntetett eljárás } \\
\text { (hiánypótlás elmulasztása, } \\
\text { felszámoló visszavonása) }\end{array}$ & 45 & 62 & 70 \\
\hline Elutasított kérelem & 39 & 44 & 20 \\
\hline Támogatott kérelem & 940 & 745 & 597 \\
\hline
\end{tabular}

Forrás: saját szerkesztés az Innovációs és Technológiai Minisztérium adatai alapján

Első ránézésre azt láthatjuk, hogy az igények folyamatosan csökkenő tendenciát mutatnak, ugyanakkor fontos arra felhívni a figyelmet, hogy a birosag.hu oldalon található ügyforgalmi adatok alapján a felszámolási eljárások száma is csökkent az elmúlt években, amit az 1. számú ábrán mutatunk be.

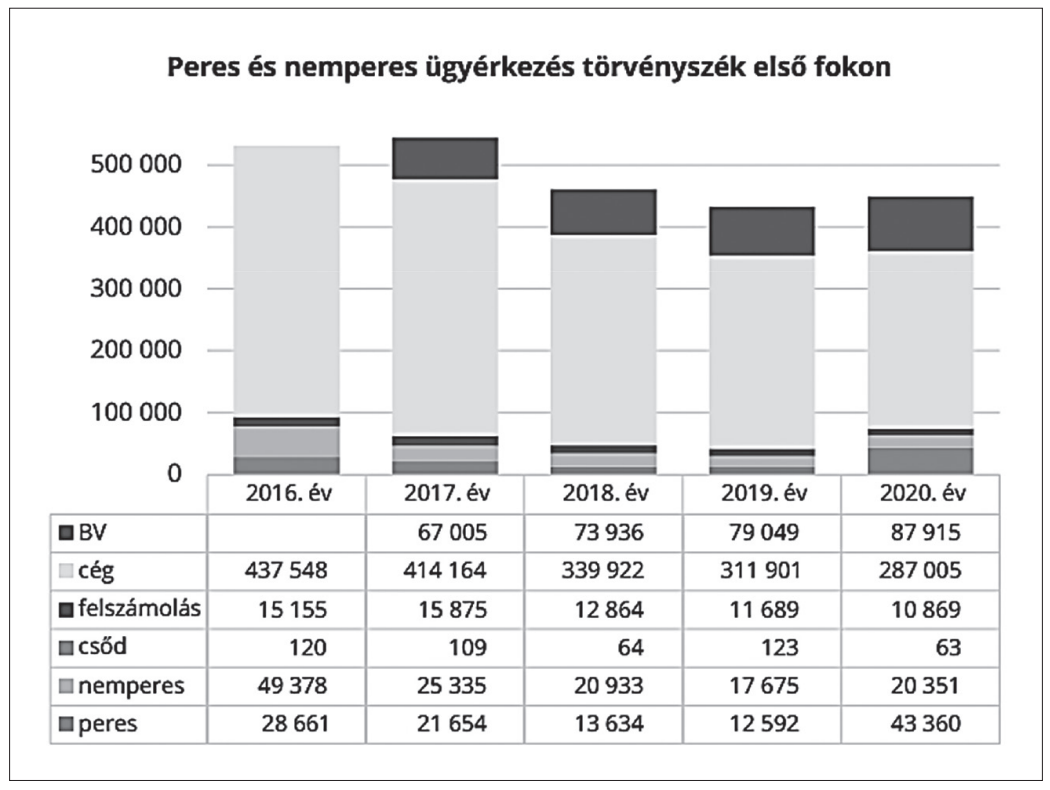

1. ábra. A Bérgarancia Alappal kapcsolatos kérelmek alakulása, 2018-2020

Forrás: Ügyforgalmi elemzés, $2020^{44}$

${ }^{44}$ Elérhető: https://birosag.hu/sites/default/files/2021-04/ugyforgalom_2020.ev_.pdf (2021. 05. 31.). 
A két adatsort összevetve ugyanakkor azt láthatjuk, hogy a bérgarancia-igények lényegesen nagyobb arányban csökkentek, mint a felszámolási eljárások száma (lásd a 2. táblázat).

2. táblázat. A két folyamat százalékos összehasonlítása

\begin{tabular}{|l|r|c|}
\hline Benyújtott bérgarancia-igénylések & Érkezés & Csökkenés \\
\hline $\mathbf{2 0 1 8}$ & 1025 & $17 \%$ \\
\hline $\mathbf{2 0 1 9}$ & 854 & $19 \%$ \\
\hline $\mathbf{2 0 2 0}$ & 692 & \\
\hline Lefolytatott felszámolási eljárások & 12864 & $9 \%$ \\
\hline $\mathbf{2 0 1 8}$ & 11689 & $7 \%$ \\
\hline $\mathbf{2 0 1 9}$ & 10869 & \\
\hline $\mathbf{2 0 2 0}$ & & \\
\hline
\end{tabular}

Forrás: saját szerkesztés a bírósági információk alapján

Az, hogy a bérgarancia-igénylések lényegesen nagyobb arányban csökkentek, mint a felszámolási eljárások száma - feltételezve, hogy a fizetésképtelenséggel érintett cégeken belül a munkavállalókkal rendelkező cégek aránya nagyjából állandó -, arra enged következtetni, hogy a jogintézmény hasznossága nem megfelelö.

Az adatsor elemzéséhez hozzátartozik még az is, hogy a 2020. évben a Gazdaságvédelmi Akcióterv végrehajtása érdekében a csődeljárásról és a felszámolási eljárásról szóló 1991. évi XLIX. törvény, valamint a cégnyilvánosságról, a bírósági cégeljárásról és a végelszámolásról szóló 2006. évi V. törvény rendelkezéseinek eltérő alkalmazásáról szóló 249/2020. (V. 28.) Korm. rendelet, majd ezt követően a későbbiekben meghozott veszélyhelyzeti intézkedések a felszámolási eljárások megindíthatóságát korlátozták, azaz a nem munkavállalói hitelezők egy időszakban nem, vagy csak korlátozottan tudtak felszámolási eljárást kezdeményezni. Ennek ellenére azonban azt feltételezzük, hogy a koronavírus negatív gazdasági hatásai a munkáltatókat ugyanúgy érintették, ami esetlegesen a látens fizetésképtelen helyzetet, végső soron a munkavállalók megélhetésének veszélyeztetését eredményezte.

Mindezekből adódóan levonható az a következtetés, amire a koronavírus-járvány is pontosan rámutatott, hogy a bérgarancia-rendszer a jelenlegi fizetésképtelenséggel összekapcsolt, a munkavállalókon kívüli tényezőkkel (felszámoló, fizetésképtelen munkáltató stb.) megjelenő jelenlegi formája nem minden esetben alkalmas a szociális szempontokat fókuszba helyező jogintézmény érvényesülésére, hiszen a kiszolgáltatott helyzetben lévő munkavállalóknak nincs konkrét ráhatásuk arra, hogy az igényüket akár önállóan, akár csoportosan érvényesíteni tudják. 


\section{Konklúzió: a Bérgarancia Alap megítélése a munkavállalói jogvédelem tükrében}

Összességében tehát megállapítható, hogy hazánkban jelentős gondot okoz a munkáltatók fizetésképtelen helyzete nemcsak saját, hanem az általuk foglalkoztatott munkavállalók megélhetésére nézve is. Az e helyzet enyhítésére létrehozott Bérgarancia Alap szabályozása, illetve az azzal szorosan összefüggő jogszabályi rendelkezések alkalmazása gyakran vet fel aggályokat a munkavállalók igényérvényesítésének támogatása szempontjából, tekintettel a korábban említett alanyi kör, illetve a kifizetés feltételeinek szükösségére, valamint az igényérvényesítésben részt vevő személyek diverzitására.

A közelmúltban eszközölt módosítások igyekeznek felvenni a versenyt az európai és nemzetközi tendenciákkal, mintegy kibővítve a szociális védelmet a munkáltató fizetésképtelensége esetén kiegyenlítetlen munkabérekkel kapcsolatban, azonban a járvány gazdasági tanulságait áttekintve láthatjuk, hogy ez a jogintézmény a jelenlegi formájában nem alkalmas maradéktalanul a kívánt cél elérésére, így a bevezetöben leírt hipotézisünket ebben a körben igazoltnak látjuk.

Ennek felismerése lehetővé teszi azt, hogy a jogalkotó felülvizsgálja, és szükség esetén módosítsa a jelenlegi szabályrendszert, és így a jogfejlődés jövőbeli eredményeként a magyar bérgarancia-szabályozás némiképp kiteljesedhet, és egy letisztult jogi kereteket magában foglaló szabályösszesség lehet, amely minden téren alkalmas a rendeltetésének megfelelő müködésre. A már végbement törvénymódosításokkal összefüggésben kirajzolódni látszik a jogalkotó szándéka, amely tágabb körben, az egyenlő bánásmód és esélyegyenlőség elvét tiszteletben tartva kívánja biztosítani azon elmaradt munkabérigények állami forrásból történő kiegyenlítését, amelyek a munkáltatónál meglévő fedezethiány és fizetésképtelenség miatt nem térülhetnének meg. $E$ törekvés a fokozottabb bérvédelmen keresztül a szociális biztonság széles körű eléréséhez vezető lépések egyikét képezi. A fentiek alapján arra következtethetünk, hogy a Bérgarancia Alapra vonatkozó szabályanyag egyre nagyobb volumenü módosításokon megy keresztül, amelyek elengedhetetlenek az Alap feladatának betöltése szempontjából. E folyamatos módosításnak, „korrektúrának" a jövőre nézve nagy jelentősége van, így létfontosságú, hogy ne szakadjon meg e folyamat.

Álláspontunk szerint a meglévő szabályanyag alkalmazásán túl érdemes lenne megfontolni egyrészt a szakszervezetek bevonását a folyamatba, a felszámolási eljárás alá került vállalkozások munkavállalóinak hatékony érdekvédelme érdekében, valamint másrészt ezen túlmenően a szükséges kezelési, ellenőrzési vagy szankcionális eszközök kollektív szerződésekben való rögzítését is átgondolásra javasoljuk.

Mindazonáltal megjegyezzük, hogy véleményünk szerint a jelen állapotában müködő Bérgarancia Alap minimális szinten megfelelő garanciális eszköz a munkavállalók igényérvényesítése szempontjából, azonban ahhoz, hogy teljes körü védőhálóként szolgáljon, szükség van a szoros együttmüködésre a foglalkoztatáspolitika egyéb szektoraival, a releváns szolgáltatások, támogatások összehangolására, valamint azok nyújtására, hiszen közös érdekünk mind a nehéz helyzetbe került munkavállalók, mind az őket foglalkoztató munkáltatók segítése. 